\title{
ESSAY
}

\section{The incredible shrinking venture capital}

\author{
Venture funding is declining quickly and is unlikely to bounce back. But less money means lower \\ expectations - good news for smaller science start-ups, says John Browning.
}

The days when stock options put Ferraris into the car parks of start-ups are over, and venture capital is drying up. In the first quarter of 2009, US venture-capital investments in the life sciences fell $40 \%$ from the fourth quarter of 2008 , in biotechnology they fell $46 \%$, and in software $42 \%$. Even investment in green technologies - such as those designed to improve energy efficiency - was down $84 \%$, more than wiping out the $54 \%$ increase from 2007 to 2008 .

This isn't necessarily all bad news. The venture-capital boom of the 1990s created expectations that many companies cannot meet. As the amount of venture capital shrinks, both venture capitalists and entrepreneurs are rethinking some of their basic assumptions. Having less money might make companies healthier, given the reduced pressure to be a skyrocketing success and the increased flexibility for business strategy and growth. Although the conventional venture-capital model has best suited fast-growing IT or biotech companies, it could begin to suit science and technology start-ups aimed at smaller markets.

Venture capitalists usually look for companies that will grow quickly - as a rule of thumb, with sales of at least US\$50 million within six years — and that can then be sold, either to a larger firm or on to the stock market. Without a sale, venture capitalists can't return profits to those who invested the money in the first place. The microelectronics and Internet booms of the 1990s and early 2000s provided both fast growth and sales; the lure of a Google-like financial cornucopia inspired a fivefold increase in the amount of capital in venture funds between 1996 and 2001. But more and bigger sales were needed to keep investors happy.

\section{Risky business}

This style of investing can build great companies. Think of Google, Intel, Apple, Cisco Systems and Genentech. Mercenary though it may be, the focus of creating a sellable company forces managers to make the most of their opportunities. Venture capitalists are also tolerant of risk: a typical fund would expect about a third of its investments to fail outright. But what venture capitalists can't tolerate is the merely average. They have a term for companies that reach, say, $\$ 10$ million in sales and neither lose so much money that they go out of business, nor grab the markets to continue growing and fetch a high sale price. They call them the 'living dead'. Where many might see a nice little company - including biotech ventures whose names would be familiar to many - a venture capitalist sees mostly frustration. Today, with capital markets crunched and sales slow, more and more investments look

Conway, recently financed her travel website by selling cupcakes.

Others have been looking harder at 'angel financing', in which wealthy individuals put their own money into deals. These individuals still want a return on their investment, but they are more willing to take it as a stream of dividends from a company that has found a valuable niche, rather than as profit from the sale of the company. Although the amount of angel financing in the United States shrank by about $26 \%$ from 2007 to 2008 , it was still about $\$ 19$ billion for 2008, not far below traditional venture capital, according to a study by the Center for Venture Research, at the University of New Hampshire in Durham. What is more promising is that the money was spread across roughly the same number of deals in 2008 as in 2007: about 55,000.

Given the lacklustre returns of traditional investment strategies, venture capitalists are also looking to do more with less. Marc Andreessen, co-founder of Netscape Communications and a pillar of the Silicon Valley establishment, recently co-launched a venture firm that plans to invest as little as $\$ 50,000$ per start-up - far less than the $\$ 3$ million considered to be a minimum by many venture capitalists. Although it is early days, efforts such as this might reshape venture capitalism. Without the weight of Googlesque expectations on their shoulders, companies that might have joined the ranks of the living dead could start to look lively. A start-up focused on a non-blockbuster drug or diagnostic test might now find itself with an attractive niche market, garnering the attention of venture capitalists who would usually have avoided this type of limited-growth company.

Smaller investments will force entrepreneurs to work harder - no more plush offices or fridges stocked with designer fruit juice. But, because the returns demanded by investors are proportional to the amounts put in, smaller investments also reduce the pressure on companies and allow them to become more flexible in their business strategies. And that is what entrepreneurship needs most.

John Browning is a writer and consultant. $\mathrm{He}$ co-founded the First Tuesday networking forums for venture capitalists and innovators.

e-mail: jb@poyais.com 